\title{
Türk Otomotiv Sektöründe Endüstri İçi Ticaretin Analizi
}

\author{
Füsun YENILLMEZ*, Mustafa GÜLLÜ**
}

\section{ÖZ}

Otomotiv sektörü bir ülkenin ekonomisini etkileyen önemli sektörlerden birisidir. Sektörün ihracat ve ithalat boyutu dikkate alınarak sektöre yönelik yapılacak her türlü çalışma önem taşımaktadır. Türkiye'nin sektördeki durum analizinin yapılması sektörü geliştirmeye yönelik Ar-Ge çalışmalarına, stratejik planlamalara ve kısa, orta ve uzun dönem hedeflerin belirlenmesine katkı sağlayacaktır. Çalışmanın amacı Türk otomotiv sektörünün dünya ticaretindeki yerini belirlemektir. Bunun için öncelikle otomotiv sektörü diş ticaretinde yer alan ürünler üç alt basamağa (digit) kadar indirilip değerlendirmeye dâhil edilmiştir. Analizlerde Grubel-Lloyd endeksi kullanılmıştır. Analizler sonucunda Türkiye'nin en yoğun Endüstri İçi Ticaret yaptığı ülkeler ürün gruplarına göre ayrı ayrı tespit edilmiştir.

Anahtar Kelimeler: Endüstri İçi Ticaret, Otomotiv Sektörü, Türkiye, Grubel-Lloyd endeksi

JEL Sinıflandırması: F14, L52, L62

\section{Analysis of Intra-Industry Trade in Turkish Automotive Sector}

ABSTRACT

The automotive sector is one of the important sectors affecting the economy of a country. Considering the export and import size of the sector, any kind of work to be done for the sector is important. The analysis of Turkey's situation in the sector will contribute to R\&D studies to develop the sector, strategic planning and determination of short, medium and long term targets. The aim of the paper is to determine the location of the Turkish automotive industry in world trade. For this purpose, firstly products in the automotive sector foreign trade were reduced to three sub-digit and included in the evaluation. Grubel-Lloyd index is used in the analysis. As a result of the analyses, Turkey has been determined separately according to the product groups of the countries that have the most intensive trade in industry.

Keywords: Intra Industry Trade, Automotive Sector, Turkey, Grubel-Lloyd index

JEL Classification: F14, L52, L62

Geliş Tarihi / Received: 11.10.2017 Kabul Tarihi / Accepted: 26.11.2017

\footnotetext{
* Doç. Dr., Eskișehir Osmangazi Üniversitesi, İİB, İktisat Bölümü, yenilmez@ ogu.edu.tr, https://orcid.org/00000001-7619-8621

**Doktora Öğrencisi, Eskişehir Osmangazi Üniversitesi, mustafagullu@ gmail.com, https://orcid.org/0000-0002-42667204
} 


\section{GİRIŞ}

Otomotiv sektörü, nihai ürünle birlikte yedek parça sektörü, imalatında kullanılan plastik, metal, kimya, demir, çelik gibi sanayi sektörü ve dağıtım, bayi, akaryakıt, elektrik, elektronik, sigorta gibi yan sektörleriyle birlikte ekonominin tümünü etkileyen önemli bir sektördür. Otomotiv sektörünün üretim aşaması, ihracat ve istihdam boyutuyla birlikte birçok sektörle yakın ilişkili olması önemini daha da artırmaktadır.

Bir otomobilin yaklaşık olarak 15.000 parçadan oluştuğu, yan sanayinin otomobil üreticilerine göre üç kat daha fazla insan istihdam ettiği, ihracatın ve ithalatın önemli bir kısmının otomotiv sektöründen oluştuğu göz önüne alındığında sektörün dünya ekonomisindeki en büyük sanayi sektörlerinden olduğu anlaşılmaktadır (Letticevd, 2010). Dünyada doğrudan ve dolaylı olarak 80 milyon kişilik istihdam yaratan otomotiv sektörü diğer sektörlerle olan güçlü ilişkileri sayesinde ekonomik büyüme üzerinde yüksek çarpan etkisine ve katma değere sahiptir. Ayrıca otomotiv sektöründe 1 kişilik istihdam artışı, diğer sektörlerde 5 kişilik istihdam artışına yol açmaktadır. İhracat, ithalat ve istihdam konusunda en büyük sektörlerden olan otomotiv sektörü Türkiye'de de önemli bir sektör konumundadır. Türkiye'nin Gümrük Birliği'ne girmesiyle Avrupa Pazarına ihracatta zorluklar yaşayan Honda, Toyota ve Hyundai gibi Asyalı otomotiv markaları Türkiye'de fabrikalar kurarak Avrupa pazarına daha kolay ihracat yapmaktadırlar(Pişkin, 2017).

Türkiye'nin ihracat ve ithalatı içinde otomotiv sektörünün önemi büyüktür. 2015 yılında Türkiye'nin toplam ihracatının içinde otomotiv ihracatının payı \%14,83, toplam ithalatının içindeki payı ise \%11,52 olarak gerçekleşmiştir. Otomotiv ihracatı 21,3 milyar dolar olarak gerçekleşirken, otomotiv ithalatı ise 23,8 milyar dolar olarak gerçekleşmiştir. Ayrıca Türkiye'nin en çok otomotiv ürünleri ihraç ettiği ülkeler \%16,3'lük pay ile Almanya, \%12,2'lik pay ile İngiltere ve $\% 9,8^{\prime}$ lik pay ile Fransa olmuştur. Türkiye'nin en çok otomotiv ürünleri ithal ettiği ülkeler \%28,4'lük pay ile Almanya, \%7,9'luk pay ile İspanya ve \%7,7'lik payla İngiltere olmuştur (T.C. Gümrük ve Ticaret Bakanlığı, 2016).

Türkiye'de otomotiv sektöründe üretim yapan firmalardan 2015 yılında yapmış oldukları ihracat rakamlarına göre oluşturulan ilk 20 firma Tablo 1'de verilmiştir:

Tablo 1: 2015 Yılı Türkiye Otomotiv Sektörü İlk 20 Sıralaması

\begin{tabular}{cll}
\hline Sektörel Sıralama & Firma Ünvanı & İhracat 2015(\$) \\
\hline $\mathbf{1}$ & Ford Otomotiv San. A.Ş. & $3.847 .112 .066,44$ \\
\hline $\mathbf{2}$ & Oyak-Renault Otomobıl Fab. A.Ș. & $2.678 .134 .392,98$ \\
\hline $\mathbf{4}$ & Tofaș Türk Otomobil Fab. A.Ș. & $2.057 .743 .801,33$ \\
\hline $\mathbf{5}$ & Kibar Diș Tic. A.Ș & $2.433 .034 .659,34$ \\
\hline $\mathbf{6}$ & Toyota Otomotıv San. Turkıye A.Ş. & $1.184 .161 .964,13$ \\
\hline $\mathbf{7}$ & Bosch San. ve Tic. A.Ș & $1.059 .074 .611,46$ \\
\hline $\mathbf{8}$ & Mercedes-Benz Türk A.Ş. & $644.985 .450,05$ \\
\hline $\mathbf{9}$ & Goodyear Lastikleri T.A.Ș. & $301.453 .980,08$ \\
\hline $\mathbf{1 0}$ & Türk Pirelli Lastikleri A.Ș & $263.163 .295,26$ \\
\hline $\mathbf{1 1}$ & Hyundai-Assan Otomotiv Sanayi Ve Ticaret A.Ș. & $263.881 .257,89$ \\
\hline $\mathbf{1 2}$ & Toyota Motor Europe Adapazarı Şubesi & $212.988 .962,76$ \\
\hline $\mathbf{1 3}$ & Maxion İnci Jant Sanayi Anonim Şirketi & $234.621 .353,17$ \\
\hline $\mathbf{1 4}$ & Cms Jant ve Makına San. A.Ș. & $187.916 .471,54$ \\
\hline
\end{tabular}




\begin{tabular}{lll}
\hline $\mathbf{1 5}$ & Adının Açıklanmasını İstemiyor & $171.945 .957,67$ \\
\hline $\mathbf{1 6}$ & Adının Açıklanmasını İstemiyor & $205.139 .423,09$ \\
\hline $\mathbf{1 7}$ & Petlas Lastik Sanayi ve Tic. A.Ş. & $147.302 .273,59$ \\
\hline $\mathbf{1 8}$ & Federal Mogul Dıș Tic. A.Ş. & $146.306 .674,42$ \\
\hline $\mathbf{1 9}$ & Valeo Otomotiv Sanayi ve Ticaret A.Ş. & $154.198 .534,18$ \\
\hline $\mathbf{2 0}$ & AutolivCankor Oto. Emniyet Sis San. ve Tic. A.Ş & $116.248 .296,40$ \\
\hline
\end{tabular}

Kaynak: (Türkiye İhracatçılar Meclisi, 2016).

Tablo-1'e göre 2015 yılında en çok ihracat gerçekleştiren firma 3.847.112.066 \$’11k ihracatı ile Ford Otomotiv San. A.Ş. olmuştur. Türkiye'de 2016 yılında üretilen araçların \%77'si ihraç edilirken \%23'ü yurtiçi pazarlara yönelmiştir. Üretim açısından firmalara bakıldığında 2016 y1lında en fazla otomotiv üretimini 383.000 adet ile Tofaş, 340.000 adetle Oyak Renault ve 334.000 adet ile Ford Otosan tarafından gerçekleşmiştir. Dördüncü sırada ise üretiminin \%90’ını ihraç eden Hyundai Assan olmuştur (Pişkin, 2017).

Otomotiv sektöründe ölçek ekonomilerinin ve ürün farklılaştırmasının öneminin yüksek olması ve endüstri içi ticaretin bu iki kavram yardımıyla açıklanması (İyibozkurt ve Başkol, 2005) bu kavramları tanımlamayı gerekli kılmaktadır.

\section{1. Ölçek Ekonomileri}

Girdi ile ürün arasındaki fonksiyonel ilişki olan üretim fonksiyonunda tüm girdi miktarlarının aynı oranda artması veya azalması ölçeğin değişmesi olarak adlandırılmaktadır. Üründeki artış oranı girdideki artış oranına eşitse ölçeğin sabit verimi, fazla ise artan verimi ve az ise azalan verimi vardır denilmektedir. Ölçeğin artan verimi ile ölçek ekonomisi farklı kavramlar olmasına karşın literatürde çokça aynı anlamda kullanılmaktadır (Sağbaş, 2004). Otomotiv sektöründe firmaların birim maliyet azaltımı ve rekabet gücünün artırımı açısından içsel ölçek ekonomisinin varlığı önem kazanmaktadır. Firma düzeyinde üretim ölçeği arttığında ortalama maliyetlerinin azaldığ 1 durum olan içsel ölçek ekonomisinde, çok sayıda otomobil üreten bir firmanın birim maliyetiaz sayıda otomobil üreten firmaya göre daha azdır. Ölçek ekonomileri sonucu firma birkaç mal veya mal grubu üzerinde uzmanlaşıp o maldan çok fazla ürettiğinde daha çok çeşitmal ürettiğindeki birim maliyetten daha düşük bir maliyet elde edilmektedir (İyibozkurt ve Başkol, 2005).

\section{2. Ürün Farklılaştırması}

Ürün farklılaştırması yatay ve dikey olarak iki ayrı farklılaştırma olarak incelenmektedir. Yatay farklılaştırmada ürünün renk, desen, modeli gibi yönlerden farklılaştırılması, dikey farklılaştırmada ise malların kalitelerinin değiştirilmesi ön plana çıkmaktadır. EİT için daha çok yatay farklılaştırma için geçerli olup gelişmiş ülkeler arasında gerçekleşmektedir. Dikey farklılaştırma kavramı ise daha çok gelişmiş ülkeler ile gelişmekte olan ülkeler arasındaki ticaret için kullanılmaktadır (Utkulu, 2005). EİT'in ölçülmesinde her endüstride yapılan mal farklılaştırmasını yatay endüstri içi dış ticaret (YEIT) ve dikey endüstri içi dış ticaret (DEIT) olarak birbirinden ayırmak gereklidir. Eğer bir endüstride yatay farklılaştırma geçerliyse EİT konusunda yapılan yorumlar genel olarak geçerlidir ancak dikey farklılaştırma yapılmışsa EITT'in yapısının tekrar irdelenmesi gerekmektedir (Şimşek,2005). 


\subsection{Endüstri İçi Ticaret (EİT)}

Endüstri içi ticaret, aynı endüstrideki ve yakın ikame olan malların hemihracatı hem de ithalatı olarak ifade edilmektedir. Hecksher-Ohlin teorisinin açıklayamadığı bu tarz ticareti endüstri içi ticaret açıklamıştır (Kutlu ve Yenilmez, 2005). Ülkelerin aynı ürünü ya da farklılaştırılmış bir ürünü ihraç ederken aynı zamanda ithal ettiği durumu ifade eden endüstri içi ticaret (EITT) sistematik olarak ilk kez Grubel ve Lloyd (1971) çalışmasında ölçülmüştür (Başkol, 2009). 1960’lı yıllarda Avrupa Ekonomik Topluluğuna üye ülkelerin ticaretlerine yönelik yapılan çalışmalar, uyum maliyetlerinin analizleri, dünya ticaretinin değişen yapısı gibi sebeplerden (Çalışkan, 2010) ve uluslararası ticaretin getirilerinin geliştirilmesi, rekabet eden bir yapının oluşturulması gibi ülkelerin refah düzeylerini etkileyen unsurlara yeni bir yaklaşım getirmesi EİT'in önemini ortaya koymuştur (Küçüksakarya, 2016).

Endüstri içi ticaretin nedenleri birkaç maddeyle sıralanabilir. Bunlar farklı ülkelerde üretilen farklılaştırılmış mal grupları, taşıma maliyeti ve üretim coğrafyası, üretiminde uzmanlaşılanmaldaki maliyet indirimleri, kayıt altına alınan ticari verilerin sınıflandırmanın genişliği, ülkelerin toplam gelir dağılımındaki farklılıklar ve ülkelerin EİT seviyelerinin farklı olması şeklinde sıralanabilir. Endüstri içi ticaretin ölçülmesinde ilk çalışma Balassa (1966)'nın Avrupa Topluluğunun üyeleri arasındaki ticaretini analiz amacıyla gerçekleştirilmiş̧ir. Ancak Grubel-Lloyd tarafından tüm endüstrilere aynı ağırlığı verdiği ve endeks hesaplamasında dış ticaret açığını dikkate almadığından dolayı eksikliği olduğu ileri sürülmüştür (Yenilmez, 2004). Literatürde yoğun bir şekilde kullanılanGrubel-Lloyd yaklaşımına göre;

$$
E I T_{i}=\frac{\left(x_{i}+m_{i}\right)-\left|x_{i}-m_{i}\right|}{\left(x_{i}+m_{i}\right)} \times 100
$$

(1) nolu denkleme göre $E I T_{i}$ ile Endüstri içi ticaret değeri $x_{i}$ ile bir ülkenin i endüstrisindeki ihracat değeri $m_{i}$ ile bir ülkenin i endüstrisindeki ithalat değerini ifade etmektedir (Grubel ve Lloyd, 1975).

$\mathrm{Bu}$ çalışmanın amacı endüstri içi ticaretle ilgili yaklaşımları inceleyerek Türk otomotiv sektörünün dünyadaki yerini tespit etmektir. Otomotiv sektöründe ülkeler arasında karşılıklı olarak yüksek kazanımların oluşması amacıyla, otomotiv sektörü dış ticaretinde yer alan ürünler üç alt basamağa kadar indirilipTürkiye'nin otomotiv sektöründe en yoğun endüstri içi ticaret yaptığı ülkeler alt gruplara göre tespit edilmiştir. Çalışmada TÜİK'in SITC Rev4 Sınıflamasına Göre Dış Ticaret endekslerinde otomotiv sektörü için kullanılan 6 alt gruba $(781,782,783,784$, 785 ve 786) ait 2002-2016 y1lı aralığına göre ithalat-ihracat grafikleri, rakamları ve GrubelLloyd endeks değerleri sunulmuştur.

\section{LITERATÜR ÖZETİ}

Son yıllarda uluslararası ticarette geleneksel modellerin yerine uluslararas1 ticaretin yönünü belirleyen temel etken olarak farklılaştırma ve buna bağlı ticaret şekli olan Endüstri İçi Ticaret (EİT) yer almaktadır. EİT'e yönelik Literatürde yer alan çalışmalar çok çeşitlilik göstermektedir. Bu nedenle ortak bir metodolojiden söz edemeyiz. Ancak bir genelleme yapacak olursak çalışmaların hem ölçme teknikleri ve endekslere, hemdeEIT'in belirleyicilerinin analizine odaklandığını söyleyebiliriz. Aynı zamanda bazı çalışmalar her ikisini de kapsamaktadır.

Yabancı literatürde EIT'in ülke ve endüstriye yönelik belirleyicilerine ilişkin ilk ampirik çalışmalardan birisi Loertscher ve Matter'in(1980) 1971-1972 yıllarında OECD ülkelerine yönelik yaptıkları çalışmadır. Bunu takip eden diğer çalışmalar Caves (1981), Toh (1982), Balassa (1986), Balassa ve Bauwers (1987), Lee (1989), Bergstrand (1990), Clark (1993), 
Hughes (1993), Stone ve Lee (1995), Hummels ve Levinsohn (1995), Clark ve Stanley (1999), Ekayaneke (2001) ve Sharma (2002) nin çalışmalarıdır.

Son yıllarda uluslararası ticarette geleneksel modellerin yerine uluslararas1 ticaretin yönünü belirleyen temel etken olarak kalite farklılıkları ön plana çıkmaya başlamıştır. Bu da yatay-dikey EİT ayrımının önemini daha çok ortaya çıkartmıştır. Kalite farklılıkları olan malların değişimi temeline dayanan dış ticaret dikey EİT olarak tanımlanmaktadır. Kalite dışında belirli niteliklere göre farklılaştırılmış malların değişimine dayalı ticarette yatay EİT olarak tanımlanmaktadır.

EİT 1980'lerden önce ölçeğe göre artan getiriler ve yatay farklılaştırılmış malların ticareti şeklinde açıklanmaktaydı. 1981'de Falvey'in çalışmasından sonra EİT benzer ürünler arasındaki kalite farklılıklarına dayalı olarak açıklanmaya başlanmıştır. Yatay-Dikey EİT hesaplamalarında birim değer kavramıla Abd-el Rahman (1991) ve Greenaway (1994,1995) katkıda bulunmuştur. Bu çalışmaları Fontagne vd. (2006), Tharakan ve Kerstens (1995), Hellvin (1996), Aturupane vd. (1997), Hu ve Ma (1999), Blanes ve Martin (2000), Gullstrand (2002), Fontagne ve Freudanberg (2002), Fukao vd. (2003), Sharma (2004), Baleix ve Egido (2005), Byun ve Lee (2005), Ando (2006), Caetono ve Galego (2007), Leitano vd. (2009), Pittiglio ve Reganati (2012), çalışmaları takip etmiş ve teoriyi bu günkü haline getirmede katkı sağlamıştır.

Endüstri İçi Ticaret ile ilgili Türkiye'de yapılan çalışmalarda çok çeşitlilik göstermektedir. Endüstri İçi Ticaret konusunda Avrupa Birliği ülkeleri, BRICS ülke grubu, Orta Asya ülkeleri gibi ülke gruplarını baz alarak yapılan çalışmalarla birlikte sektör odaklı çalışmalarda bulunmaktadır. Bu alanda yapılan çalışmalardan Küçükahmetoğlu (2001)tüm dünya ülkelerinin 1989-1998 yılları arasında Grubel-Lloyd endekslerini hesapladığı çalışmada endeksin dönem boyunca arttığını ifade etmiş ve Türkiye'nin EİT seviyesinin gelişmiş ülkelere göre düşük olduğu sonucuna varmıştır. Şimşek (2015) ise yatay ve dikey EİT kavramlarına yer vererek Türkiye'de düşük kalite dikey endüstri içi dış ticaretin baskın olduğu sonucuna varmıştır.

Aydın (2008) çalışmasında Türkiye'nin toplam ticareti ölçek ekonomileri ve uzmanlaşma temelli olduğunu ve EITT oranının \%40 seviyesinde olduğunu ifade etmiş, Aydın (2010)'da ise Türkiye'nin çeşitli ülkelerle yaptığı ticari hizmetler analiz edilerek özellikle Almanya ve Fransa'nın bu sektörde rakip ekonomiler olduğunu vurgulamıştır.

Başkol (2009), Türkiye'de endüstri içi ticaretin daha çok standart teknolojiye ait ürünlerde gerçekleştiğini, yüksek teknolojiye sahip endüstrilerin endeks değerlerinin düşük olduğunu ifade etmiştir. Başkol (2010) başka bir çalışmasında, Türkiye ile Orta Asya Cumhuriyetleri arasındaki EİT'i analiz etmiş ve EİT'nin payı süreç içinde artmış olsa da endüstrilerin büyük bir kısmında EITT'in yetersiz olduğunu ifade etmiştir.

Şahin (2015) çalışmasında, Türkiye'nin tekstil ve hazır giyim sektörünün AB-15 ülkelerindeki, Şahin (2016a) çalışmasında yaş meyve ve sebze sektörünün BRICS ülkelerindeki ve Şahin (2016b) çalışmasında ise ormana dayalı sektörlerin EITT yapısını analiz etmiş̧tir. Tekstil sektörü üzerinde EİT'yi inceleyen diğer bir çalışma olan Özkaya (2010) ise 1989-2009 döneminde kişi başına düşen gelir ve ölçekekonomilerinin EİT düzeyini olumlu etkilediği, doğrudan yabancı yatırımı olumsuz etkilediği sonuçlarına ulaşmıştır.

Akal (2008) çalışmasında Türkiye'nin Ortadoğu sınır ülkeleriyle yaptığı dış ticareti incelemiştir. Türkiye'nin bu ülkelere olan ihracatın emek yoğun mallardan sermaye yoğun ve teknoloji içerikli mallara yoğunlaşmış olduğunu, ayrıca petrol sektöründe de bir endüstri içi ticaretin oluşmaya başladığını ifade etmiştir. Aynı ülke grubuyla analizi yapan Erlat ve Erlat (2012) ise Türkiye'nin Ortadoğu ülkeleriyle EİT seviyesinin çok düşük olduğunu, en yüksek düzeyde olan İsrail ve Mısır'ın EİT payının yüzde 10 civarında olduğunu ortaya koymuştur. 
Emirhan (2014) ise 1985-2010 yılları arasında Türkiye'den göç akımının yoğun olduğu 20 ülke üzerinde yaptığı analizde göç akımlarının endüstri içi ticareti azalttığını ifade etmiştir. 1990-2001 dönemi için Türkiye'de Cam ve Seramik sektörünün EİT seviyesini inceleyen Konyalı ve Emirhan (2004) ise EİT’nin seramik sektöründe düşük, cam sektöründe ise düşme eğiliminde olduğunu ve iki sektörde de $\mathrm{AB}$ piyasasındaki talebe uyumun yüksek olduğu sonucuna varmışlardır.

Türkiye'nin Avrupa Birliği (15) ülkeleriyle endüstri içi ticaretini inceleyen Altay ve Şen (2009) Türkiye'nin 1995-2007 yılları arasında Türkiye'nin rakiplerine oranla daha yüksek bir artış trendine sahip olduğunu ortaya koymuştur. Altay vd. (2015)'in yine aynı ülke grubuyla yaptığı bir diğerçalışmada da Türkiye'nin düşük katma değerli ürünlerde avantajlı olduğu sonucuna varmıştır. Çalışkan (2010) ise AB ülkeleri üzerinde 1990-2007 döneminde yaptığ çalışmada EITT oranı istikrarlı bir şekilde artmasına rağmen, Türkiye'nin AB ile ticaretinin endüstriler arası ticaret şeklinde olduğu sonucuna varmıştır. Türkiye'nin AB karşısında ileri teknoloji içerikli sektörde rekabet gücünün düşük olduğunu ifade eden Eşiyok (2014), düşük teknolojide rekabetin yüksek olduğunu gözlemlemiştir.

Erün (2010) ise $A B(15)$ ve $A B(21)$ arasında gıda ve canlı hayvan sektörü üzerinde yaptığı analizde yüksek kalitede dikey EİT yapısı olduğunu ancak tek tek ülkeler için dikey EİT yapısının düşük olduğunu gözlemlemiştir. Serbest Ticaret anlaşmaları kapsamında Türkiye'nin dış ticaret yapısında 1993-2012 yılları arasındapanel veri analizi yaparak EİT'nin payını inceleyen Küçüksakarya (2016), Türkiye'nin gerçekleştirdiği ticaret şeklinin tamamlayıcı olduğu, rekabetçi yapıda olmadığı sonucuna varmıştır

Şentürk (2014) çalışmasındaTürkiye'nin 1990-2013 yılları arasında seçilmiş ülkelerle EİT seviyesinin 23 yıl içinde yükselen bir seyir izlediğini gözlemlemiştir. Şentürk (2016) çalışmasında EİT'nin belirleyicilerine yönelik temel literatür çalışması yapmıştır. Şentürk ve Kösekahyaoğlu (2014) ise Türkiye'nin EİT potansiyelini 1995-2012 dönemi için ülke ve politika temelli belirleyiciliğine ilişkin kurduğu modeli panel veri yöntemi ile analiz etmiş, Şentürk ve Kösekahyaoğlu (2015) çalışmasında ise EİT değerlerinin genellikle düşük veya orta teknolojili mallarda yüksek değerler taşıdığı sonucuna varmışlardır.

Otomotiv şirketlerinin maliyetleri düşürme ve gelişmekte olan piyasalarda nihai müşteriye yakın olma amacıyla üretim yerlerini değiştirmelerini Macaristan, Çek Cumhuriyeti ve Polonya örneğinde inceleyen Havas (1997), bu ülkelerin Ar-Ge imkânlarının teşvik etme, eğitim ve öğretim için yeterli fonlar sağlama ve düşük teknolojiye sahip olmaktan kaçınma gibi öneriler sunmuştur.

\section{VERİ SETİ VE YÖNTEM}

Bu çalışmada TÜIK' in dış ticaret istatistiklerinden alınan verilere göre Türkiye ile tüm dünya ülkeleri arasında otomotiv sektöründe Grubel-Lloyd endeksleri hesaplanarak Endüstri içi dış ticaretin seviyesi hesaplanmıştır.

\section{1. Çalışmada Kullanılan Veriler:}

TÜİK'in SITC Rev4 Sınıflamasına Göre Dış Ticaret endekslerinde otomotiv sektörü için kullanılan gruplar ve kodları aşağıdaki gibi alt gruplara ayrılmıştır:

I. $\quad 781$ - Motorlu yolcu taşıtları (binek otomobilleri vb.)

II. 782 - Eşya taşımaya mahsus motorlu taşııtlar 
III. $\quad 783$ - Başka yerde belirtilmeyen motorlu karayolu taşıtları

IV. $\quad 784$ - Motorlu taşıtların aksam ve parçaları ile şase ve karoserleri $(772,781,782,783$ için)

V. 785 - Motosikletler, bisikletler, hasta-sakatlar taşıyıcılar, vb. ve bunların aksam parçaları

VI. $\quad 786$ - Römorklar ve yarı römorklar

Motorlu kara taşıtları,bisiklet ve motosikletler ve bunların aksam ve parçaları sektöründeki alt grupların ihracat ve ithalattaki ağırlıkları yıllara göre değişiklik arzetmektedir. Alt grupların2016 yılındaki ihracat veithalat ağırlıklarına göre grafiği Şekil-1'deki gibidir:
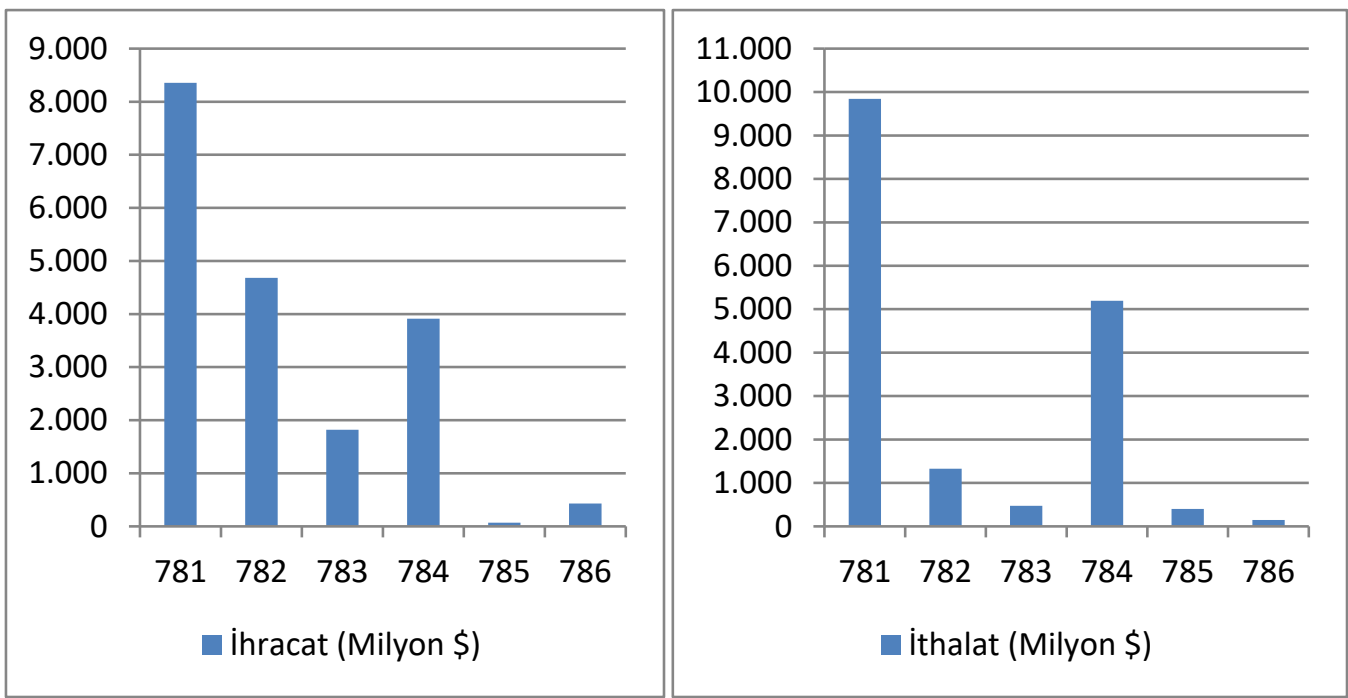

Şekil 1:Türkiye'nin 2016 Yılında Otomotiv Sektörünün Alt Gruplarının Toplam Otomotiv İhracat ve İthalatı İçindeki Payları (Milyon \$)

Kaynak: (TÜİK, 2017).

Şekil-1'e göre en çok ihraç yapılan alt gruplar 781 Motorlu yolcu taşıtlarında, en az olan alt grup ise 785 Motosikletler, bisikletler, hasta-sakatlar taşıyıcılaralt grubu olmuştur. Otomotiv alt gruplarından2016 yılında en çok ithal yapılan alt gruplar 781 Motorlu yolcu taşıtlarında ve 784 Motorlu taşıtların aksam ve parçaları ile şase ve karoserlerialt grubu olmuştur.

\section{BULGULAR VE DEĞERLENDİRME}

Çalışmada 2016 yılı otomotiv sektörü alt gruplarının her birisi için Türkiye'nin diğer ülkelerle endüstri içi rekabetinin analizi için Grubel-Lloyd endeksleri hesaplanıp en yüksek endekse sahip olan 10 ülke tabloda listelenmiştir. Deviren (2004) çalışmasında, Türkiye ile Avrupa Birliği arasındaki sınai ürünlerin endüstri ticaretini ele almış ve Grubel-Lloyd 0,50 endeks değerinin altında kaldığı ülkeler arasında dış ticaretin endüstriler arası ticaret (EAT) yapısına sahip olduğunu ifade etmiştir. Bu çalışmada da kritik değer 0,50 olarak alınacak olup, bu değerin üstünde endeks değerine sahip ülkelerle endüstri içi ticaret yapısına sahip olduğu ifade edilecektir. Türkiye'nin781, 782, 783, 784, 785 ve 786 altgruplarına ait 2002-2016 y1lı aralığına göre ithalat-ihracat grafikleri, 2016 yılihhracat-ithalat rakamları ve Grubel-Lloyd endeks değerleri verilmiştir. 


\subsection{1-Motorlu Yolcu Taşıtları (Binek Otomobilleri vb.)}

Motorlu yolcu taşıtları (binek otomobilleri vb.)alt grubunda Türkiye'nin 2002-2016 yılları arasındaki ihracat ve ithalatın grafiği aşağıdaki gibidir:

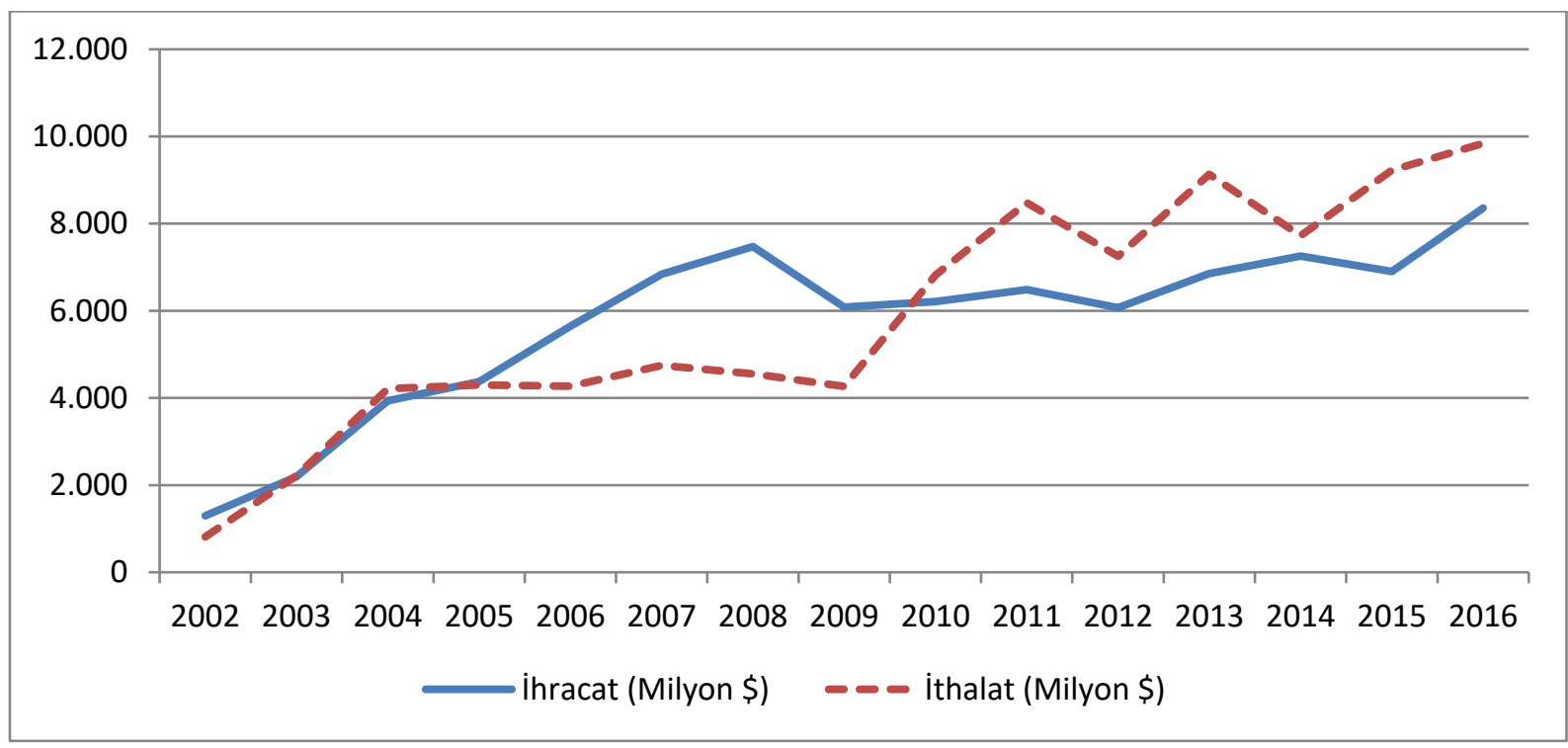

Şekil 2: Türkiye'nin 2002-2016 Yılları Arasında 781-Motorlu Yolcu Taşıtları İhracat ve İthalatı (Milyon \$)

Kaynak: (TÜiK, 2017).

Şekil 2'ye göre 2004-2009 arası durağan seyreden ithalatın daha sonraki yıllarda artış trendinde olduğunu, ihracatın 2008 y1lındaki düşüş hariç tüm y1llarda artış trendine sahip olduğu görülmektedir. Motorlu yolcu taşıtlarının olduğu grubun endeks sıralamaları ve 2016 yılı ihracatithalat rakamları Tablo 2'de sunulmuştur:

Tablo 2: 781-Motorlu Yolcu Taşıtları (Binek Otomobilleri vb.)

\begin{tabular}{llll}
\hline Ülke adı & İhracat $(\$)$ & Ithalat(\$) & Grubel-Llovd Endeksi \\
\hline İngiltere & 744.599 .996 & 785.598 .362 & 0,97 \\
\hline Sirbistan & 23.116 .988 & 15.247 .501 & 0,79 \\
\hline ABD & 70.227 .643 & 128.729 .308 & 0,70 \\
\hline Polonya & 268.425 .661 & 556.329 .668 & 0,65 \\
\hline Finlandiya & 38.992 .843 & 18.097 .617 & 0,63 \\
Macaristan & 131.596 .189 & 285.810 .478 & 0,63 \\
\hline İspanya & 646.219 .896 & 1.493 .036 .969 & 0,60 \\
\hline Fransa & 1.127 .611 .666 & 408.217 .095 & 0,53 \\
\hline Fas & 114.497 .373 & 367.515 .160 & 0,47 \\
\hline Meksika & 57.298 .951 & 195.272 .173 & 0,45 \\
\hline
\end{tabular}

Kaynak: (TÜIK, 2017).

Tablo 2'ye göre Motorlu yolcu taşıtları, binek otomobilleri alt grubunda Türkiye ile en yüksek EITT seviyesine sahip ülke İngiltere'dir. Ardından Sırbistan ve ABD gelmektedir. Türk otomotiv sektörünün en büyük ihracat pazarlarından olan İngiltere hafif ticari araçlarının nerdeyse tamamını Koç Holding bünyesinde bulunan Ford Otosan ve Tofaş'tan ihraç etmektedir. 
Ford, Transit modelini 2012 yılına kadar hem Türkiye hem de İngiltere'de üretirken 2012 sonrasında tek üretim merkezi olarak Gölcük'ü tercih etmiştir (Yenigün,2016). Buna karşılık, İngiltere'de üretim yapan BMW, Ford, Honda, Nissan, Toyota gibi firmalardan yüksek katma değerli lüks ve normal binek araç ithalat edilmektedir (Londra Ticaret Müşavirliği,2007).Ford Otosan, Transit Connect markasını, Tofaş ise Doblo'yu Ram markasıyla ABD'ye ihraç eden Türkiye, aynı zamanda Toyota'nın SUV modeli ve CH-R modelini de ihraç etmeyi planlamaktadır (Özpeynirci, 2016). Binek otomobil alt grubunda İngiltere ile Türkiye arasında yüksek bir endüstri içi ticaret olması, bu ülkeyle uzmanlaşmaya giderek ürettiği binek otomobil çeşidini azaltarak daha verimli ve düşük maliyetle üretim yapıp ihraç etmekte, diğer ülkelerden de o ülkenin uzmanlaştığ ürünleri ithal ederek daha çok ürün çeşitliliğine ulaşmaktadır.781 alt grubundaGrobal Lloyd (GL) endeks değerlerine göre Türkiye ile İngiltere arasında yüksek düzeyde endüstri içi ticaret (EITT) yapısı mevcut iken, GL değeri 0.50'nin altında olan Fas ve Meksika ile yapılan ticaretin endüstriler arası ticaret (EAT) yapısında olduğu sonucuna ulaşılmıştır.

\subsection{2-Eşya Taşımaya Mahsus Motorlu Taşıtlar}

Eşya taşımaya mahsus motorlu taşıtlar alt grubunda Türkiye'nin 2002-2016 yılları arasındaki ihracat ve ithalat grafiği aşağıdaki gibidir:

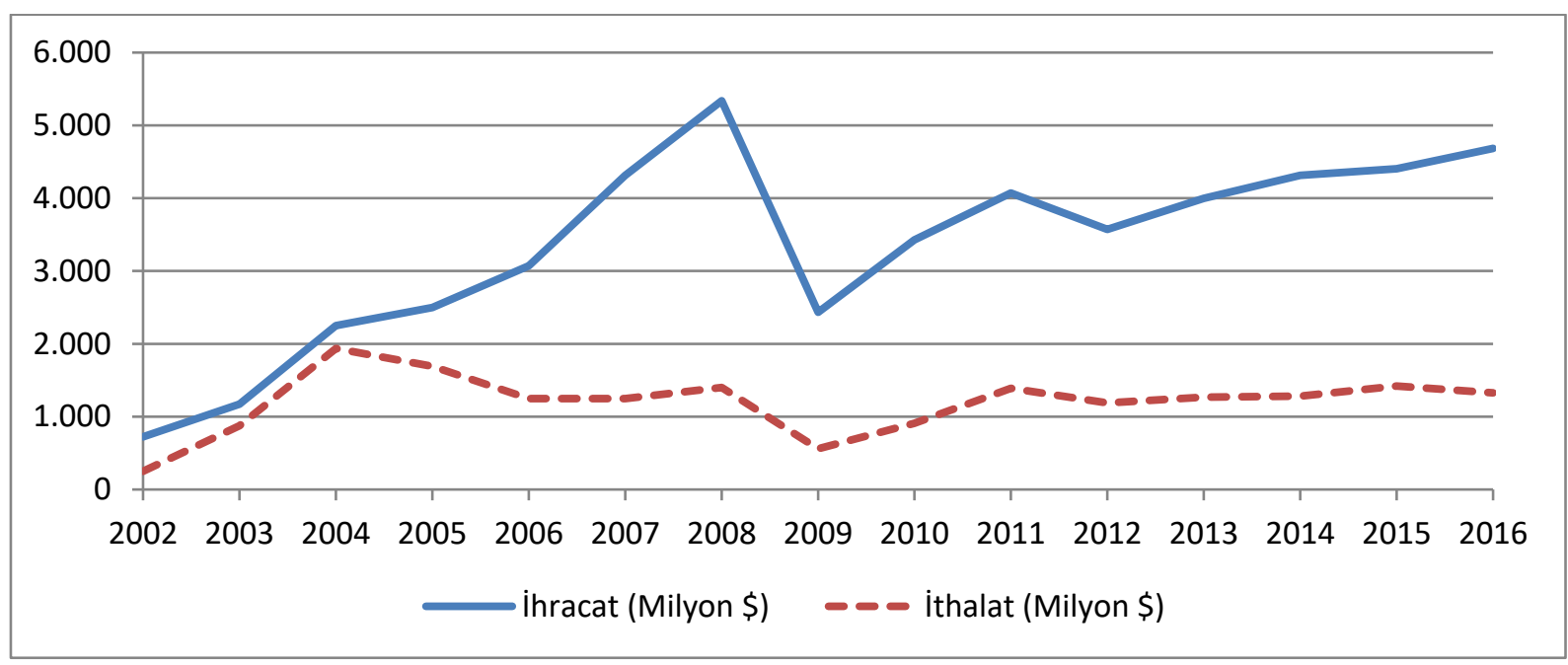

Şekil 3: Türkiye'nin 2002-2016 Yılları Arasında 782-Eşya Taşımaya Mahsus Motorlu Taşıtların İhracat ve İthalatı (Milyon \$)

Kaynak: (TÜiK, 2017).

Şekil 3'e göre Türkiye'nin eşya taşımaya mahsus motorlu taşıtların ihracatına ithalata göre bir üstünlüğe sahip olduğu görülmektedir. İhracatın ABD'de 2007 sonuna doğru meydana gelen finansal krizin, diğer ülkelere de yayılarak küresel bir krize dönüştügü yıllardaki düşüşten sonraki tüm dönemlerde arttığı, ithalatın ise 2004 yılındaki zirve değerinden sonra bir düşüş trendine girdiği ve ardından da durağan bir seyir izlediği görülmüştür. Eşya taşımaya mahsus motorlu taşıtların olduğu grubun endeks siralamaları ve 2016 yılı ihracat-ithalat rakamlarıTablo 3'de sunulmuştur: 
Tablo 3: 782-Eşya Taşımaya Mahsus Motorlu Taşıtlar

\begin{tabular}{llll}
\hline Ülke adı & İhracat (\$) & İthalat (\$) & Grubel-Lloyd Endeksi \\
\hline Almanya & 355.196 .742 & 360.468 .672 & 0,99 \\
\hline Özbekistan & 383.656 & 394.000 & 0,98 \\
\hline Polonya & 44.923 .890 & 42.673 .638 & 0,97 \\
\hline Avusturya & 21.144 .338 & 15.186 .054 & 0,83 \\
\hline Hırvatistan & 14.174 .594 & 9.511 .740 & 0,80 \\
\hline İtalya & 641.878 .369 & 235.021 .652 & 0,53 \\
\hline İran & 2.716 .081 & 963.701 & 0,52 \\
\hline İspanya & 220.233 .204 & 76.379 .485 & 0,51 \\
\hline Kirgizistan & 185.000 & 577.249 & 0,48 \\
\hline Finlandiya & 1.782 .237 & 5.737 .032 & 0,47 \\
\hline
\end{tabular}

Kaynak: (TÜİK, 2017).

Tablo 3'e göre Türkiye ile en yüksek EİT seviyesine sahip ülke Almanya'dır. Almanya da Türk vatandaşlarının yoğun bir nüfusa sahip olması, Almaya ile Türkiye'nin tarihi, sosyal ve ekonomik ortak noktalarının çok oluşu ve Almanya'nın geleneksel bir ticaret ortağı oluşu (Aydın, 2010), otomotiv sektöründe eşya taşımaya mahsus motorlu taşıltar alt grubunda EİT’ye de yansıdığı görülmüştür. Özbekistan ile EİT endeksi yüksek olmasına rağmen ihracat ve ithalat hacmi oldukça düşüktür. İtalya ve İspanya bu alt grupta en çok ihracat yapılan ülkeler olmasına karşın ithalat oranı düşüktür. 782 alt grubunda GL endeks değerlerine göre Türkiye ile Almanya, Özbekistan ve Polonya arasında yüksek düzeyde EİT yapısı mevcut iken, GL değeri 0.50'nin altında olan Kırgızistan ve Finlandiya ile yapılan ticaretin EAT yapısında olduğu sonucuna ulaşılmıştır.

\subsection{3-Başka yerde belirtilmeyen motorlu karayolu taşıtları}

Başka yerde belirtilmeyen motorlu karayolu taşıtları alt grubunda Türkiye'nin 20022016 yılları arasındaki ihracat ve ithalat grafiği aşağıdaki gibidir: 


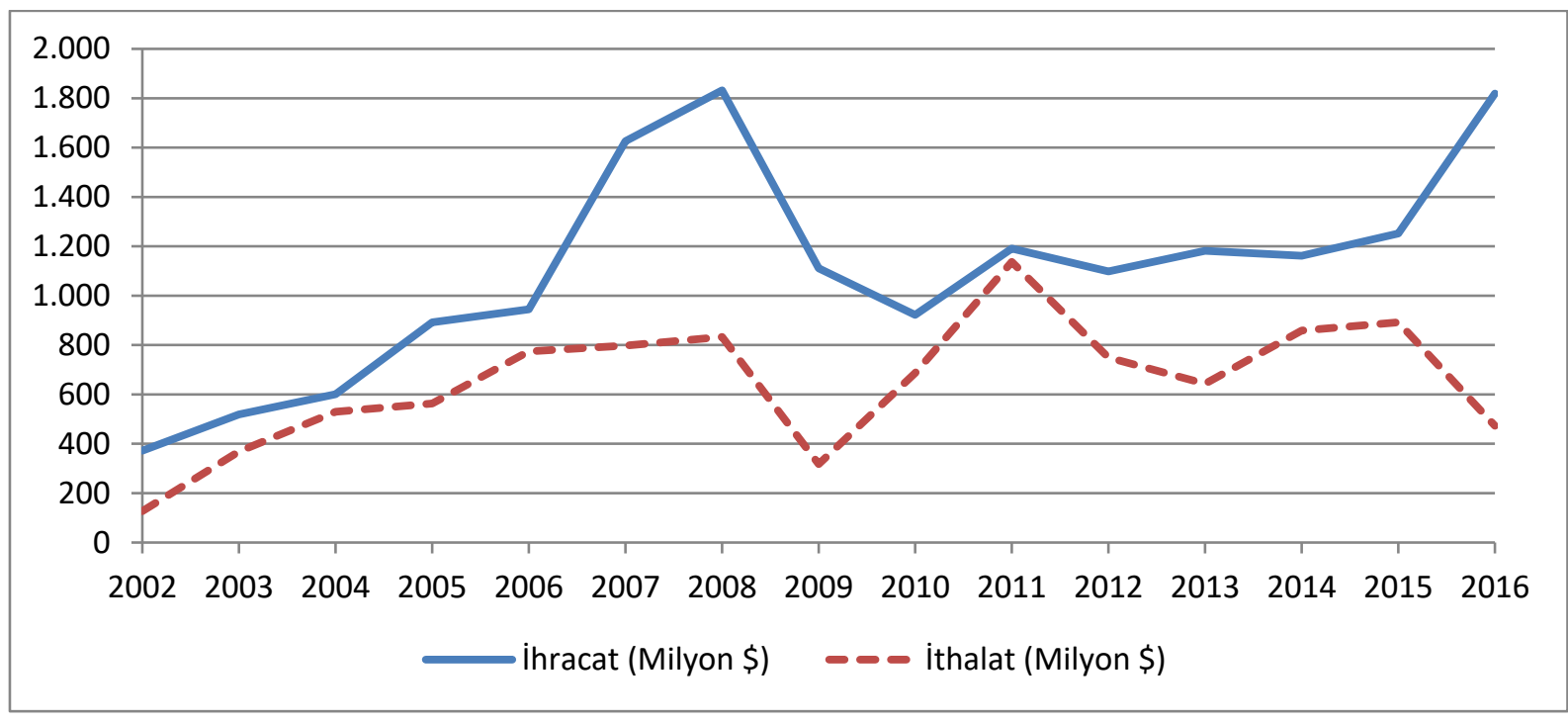

Şekil 4: Türkiye'nin 2002-2016 Y1lları Arasında 783-Başka Yerde Belirtilmeyen Motorlu Karayolu Taşıtlarının İhracat ve İthalatı (Milyon \$)

Kaynak: (TÜIK, 2017).

Şekil 4'e göre ihracat seviyesi ithalat seviyesinin üzerinde olmakla birlikte son y1llarda ihracat seviyesi artarken ithalat seviyesinin azaldığ 1 ve ihracat ile ithalat arasındaki makasın açıldığ görülmektedir.

Başka yerde belirtilmeyen motorlu taşıtlar iki alt grubu içermektedir. Bunlar;

783.1 - Sürücü dâhil olmak üzere on veya daha fazla kişinin taşınması için motorlu taşıtlar

783.2 - Yarı römorklar için yol traktörleri (UNSD, 2017).

Grubun endeks sıralamaları ve 2016 yılı ihracat-ithalat rakamları Tablo 4'de verilmiştir:

Tablo 4: 783-Başka Yerde Belirtilmeyen Motorlu Karayolu Taşıtları

\begin{tabular}{llll}
\hline Ülke adı & İhracat $(\$)$ & Ithalat(\$) & Grubel-Lloyd Endeksi \\
\hline Belçika & 29.983 .687 & 34.998 .743 & 0,92 \\
\hline Almanya & 392.902 .650 & 198.492 .896 & 0,67 \\
\hline Portekiz & 10.110 .011 & 4.006 .022 & 0,56 \\
\hline İsvec & 17.736 .797 & 6.360 .460 & 0,52 \\
\hline İspanya & 105.388 .765 & 32.724 .492 & 0,47 \\
\hline Hollanda & 32.582 .055 & 134.898 .827 & 0,38 \\
\hline İran & 505.322 & 79.682 & 0,27 \\
\hline Fransa & 330.001 .901 & 47.052 .764 & 0,24 \\
\hline Polonya & 102.267 .362 & 12.618 .041 & 0,21 \\
\hline Avusturya & 35.404 .107 & 910.566 & 0,05 \\
\hline
\end{tabular}

Kaynak: (TÜİ, 2017).

Tablo 4'e göre en yüksek EİT'ye sahip olan ülke Belçika olmakla birlikte ihracat ve ithalat hacmi Almanya ve Fransa'ya göre çok düşük seviyede bulunmaktadır. Almanya, Fransa, Polonya ve İspanya'da ihracat miktarları ithalattan daha yüksek seviyededir. 783 alt grubunda 
GL endeks değerlerine göre Türkiye ile Belçika arasında yüksek düzeyde EİT yapısı mevcut iken, GL değeri 0.50’nin altında olan İspanya, Hollanda, İran, Fransa, Polonya ve Avusturya ile yapılan ticaretin EAT yapısında olduğu sonucuna ulaşılmıştır.

\subsection{4-Motorlu Taşıtların Aksam ve Parçaları İle Şase ve Karoserleri (772,781,782,783 İçin)}

Motorlu taşıtların aksam ve parçaları ile şase ve karoserleri alt grubunda Türkiye'nin 2002-2016 yılları arasındaki ihracat ve ithalatın grafiği şekil 5'deki gibidir:

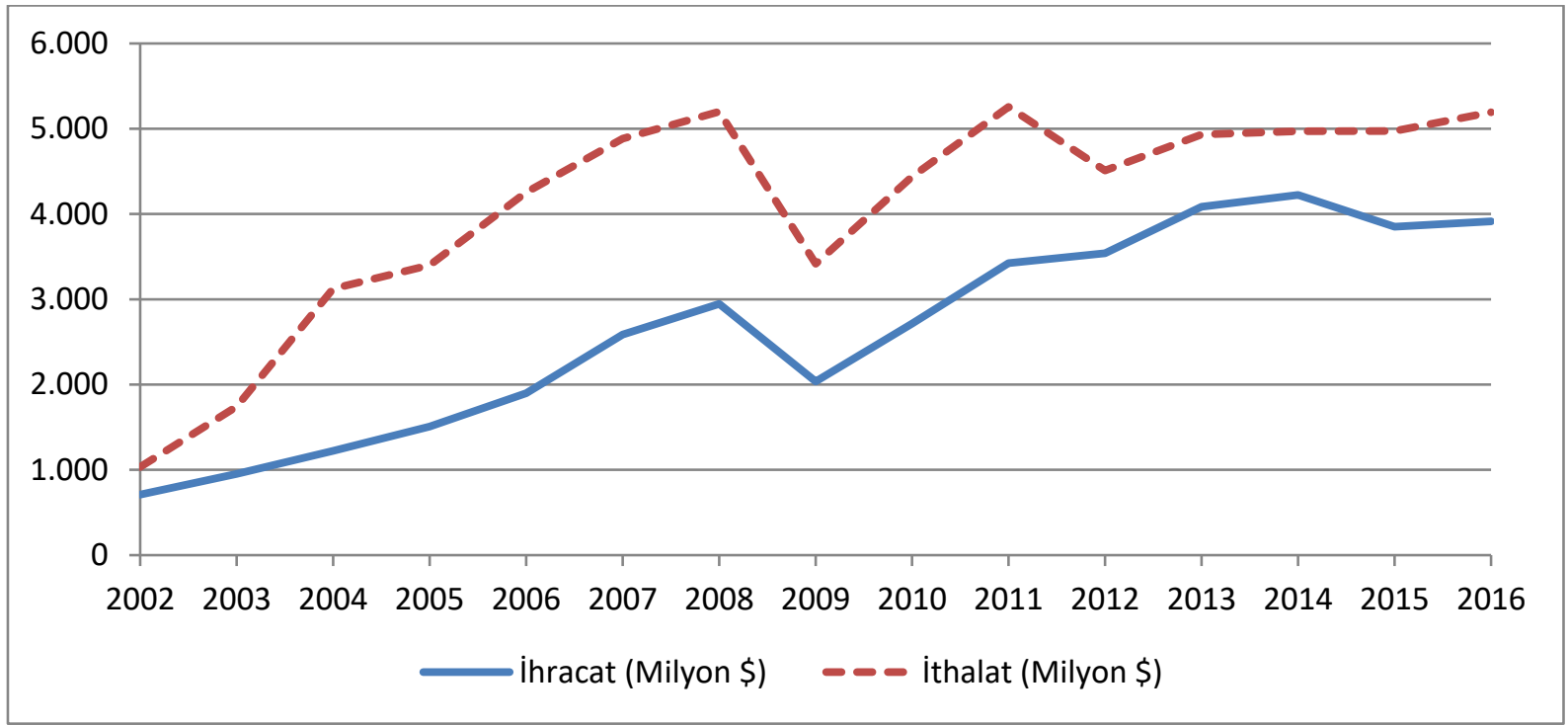

Şekil 5: Türkiye'nin 2002-2016 Yılları Arasında 784-Motorlu Taşıtların Aksam ve Parçaları İle Şase ve Karoserlerinin İhracat ve İthalatı (Milyon \$) Kaynak: (TÜİK, 2017).

Şekil 5'e göre Motorlu taşıtların aksam ve parçaları alt grubunda yıllara göre ithalatın ihracata göre üstünlüğü görülmektedir. 2008 finansal kriziyle düşüşe geçen eğilim 2009'dan itibaren toparlanma sürecine girerek hem ithalat hem ihracatta artan bir seyir izlemektedir. Motorlu taşıtların aksam ve parçaları ile şase ve karoserleri alt grubun endeks sıralamaları ve 2016 y1lı ihracat-ithalat rakamlarıTablo 5'de sunulmuştur: 
Tablo 5: 784-Motorlu Taşıtların Aksam ve Parçaları ile Şase ve Karoserleri

\begin{tabular}{llll}
\hline Ülke adı & İhracat $(\$)$ & İthalat $(\$)$ & Grubel-Lloyd Endeksi \\
\hline Fransa & 370.484 .908 & 424.621 .118 & 0,93 \\
\hline Romanya & 162.465 .828 & 140.594 .111 & 0,92 \\
\hline Almanya & 793.932 .328 & 1.088 .259 .999 & 0,84 \\
\hline İspanya & 187.466 .301 & 257.688 .456 & 0,84 \\
\hline Vietnam & 1.962 .806 & 1.405 .810 & 0,83 \\
\hline Kanada & 7.776 .690 & 5.130 .591 & 0,79 \\
\hline Avusturya & 31.162 .890 & 20.505 .207 & 0,79 \\
\hline İngiltere & 292.852 .566 & 179.915 .505 & 0,76 \\
\hline Macaristan & 45.090 .823 & 83.501 .990 & 0,70 \\
\hline İrlanda & 7.024 .870 & 3.733 .961 & 0,69 \\
\hline
\end{tabular}

Kaynak: (TÜİK, 2017).

Tablo 5'e göre hem EİT yüksek olduğu hem de ihracat ve ithalat hacimlerinin yüksek olduğu ülkeler Fransa, Romanya, Almanya ve İspanyadır. Bu ülkelerle olan EİT performansının yüksekliği ticaretin iki yönlü olarak gerçekleştiğini göstermektedir.784 alt grubunda GL endeks değerlerine göre Türkiye ile Fransa ve Romanya arasında yüksek düzeyde EİT yapısı mevcuttur. 784 alt grubundaTürkiye'nin 19 ülke ile ticaret yapısı EİT düzeyinde olduğu, diğer ülkelerle EAT yapısında olduğu bulunmuştur.

\subsection{5-Motosikletler, Bisikletler, Hasta-Sakatlar Taşıyıcılar, vb. ve Bunların Aksam Parçaları}

Motosikletler, bisikletler, hasta-sakatlar taşıyıcılar, vb. ve bunların aksam parçaları alt grubunda Türkiye'nin 2002-2016 yılları arasındaki ihracat ve ithalatın grafiği aşağıdaki gibidir:

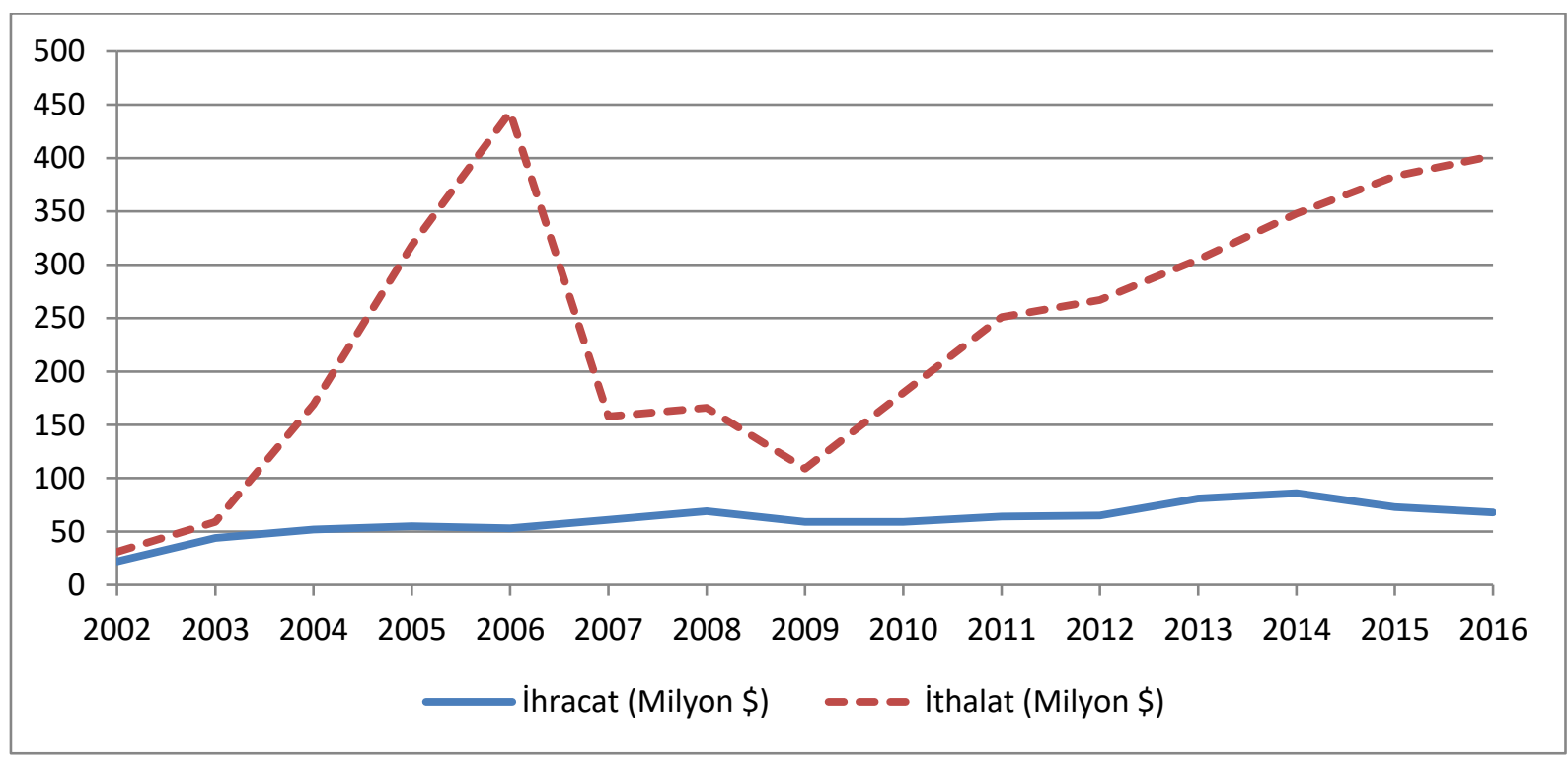

Şekil 6: Türkiye'nin 2002-2016 Yılları Arasında 785-Motosikletler, Bisikletler, Hasta-Sakatlar Taşıyıcılar, vb. ve Bunların Aksam Parçaları İhracat ve İthalatı (Milyon \$) Kaynak: (TÜIK, 2017). 
Şekil 6'da ithalatın ihracata göre üstünlüğü ve ithalat trendinin 2008 finansal krizi öncesinde en düşük seviyeye ulaştığını, kriz sonrasında ise eski seviyesine kadar artış gösterdiği görülmektedir. Motosikletler, bisikletler, hasta-sakatlar taşıyıcılar, vb. ve bunların aksam parçaları alt grubun endeks sıralamalarıve 2016 yılı ihracat-ithalat rakamları Tablo 6'de sunulmuş̧tur:

Tablo 6: 785-Motosikletler, Bisikletler, Hasta-Sakatlar Taşıyıcılar, vb. ve Bunların Aksam Parçaları

\begin{tabular}{llll}
\hline Ülke adı & İhracat $(\$)$ & İthalat $(\$)$ & Grubel-Lloyd Endeksi \\
\hline Kanada & 13.329 & 17.962 & 0,85 \\
\hline Polonya & 241.601 & 356.363 & 0,80 \\
\hline Hong Kong & 911 & 1.660 & 0,70 \\
\hline İspanya & 1.841 .722 & 859.831 & 0,63 \\
\hline Almanya & 5.927 .503 & 14.325 .288 & 0,58 \\
\hline Fransa & 8.077 .292 & 20.850 .014 & 0,55 \\
\hline İtalya & 3.985 .214 & 12.185 .880 & 0,49 \\
\hline Avustralya & 38.501 & 9.752 & 0,40 \\
\hline Danimarka & 328.955 & 83.125 & 0,40 \\
\hline İngiltere & 5.611 .410 & 1.411 .560 & 0,40 \\
\hline
\end{tabular}

Kaynak: (TÜiK, 2017).

Tablo 6'ya göre Motosikletler, bisikletler, hasta-sakatlar taşıyıcılar alt grubunda Fransa, Almanya ve İtalya ile ihracat-ithalat hacimleri yüksek olmasına karşın EİT performansı düşük kalmıştır. Kanada ve Polonya ile EİT yüksek olmasına karşın dış ticaret hacminin yüksek olmadığ1 görülmektedir.785 alt grubundaGL endeks değerlerine göre Türkiye ile Kanada ve Polonya arasında yüksek düzeyde EİT yapısı mevcut iken, GL değeri 0.50'nin altında olan İtalya, Avustralya, Danimarka ve İngiltere ile yapılan ticaretin EAT yapısında olduğu sonucuna ulaşılmıştır.

\subsection{6 - Römorklar Ve Yarı Römorklar}

Römorklar ve yarı römorklaralt grubunda Türkiye'nin 2002-2016 yılları arasındaki ihracat ve ithalatın grafiği aşağıdaki gibidir: 


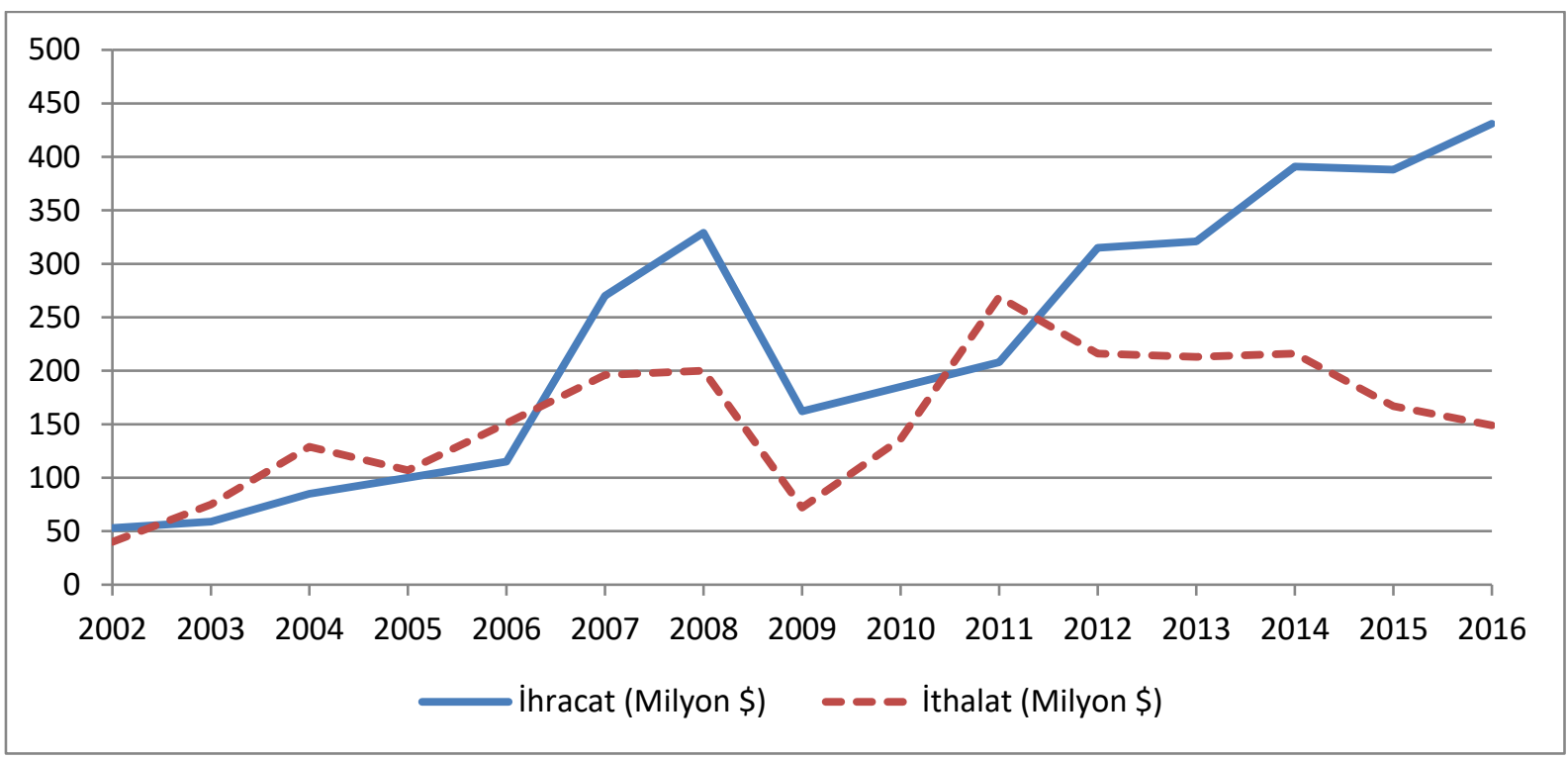

Şekil 7: Türkiye'nin 2002-2016 yılları arasında 786-Römorklar ve yarı römorklar ihracat ve ithalatı (milyon \$)

Kaynak: (TÜİK, 2017).

Şekil 7'e göre 2011 yılına kadar dalgalı bir trende sahip olan ihracat ithalat ilişkisi, 2011 y1lından sonra ihracat yoğunluklu olarak bir artış göstermektedir. Buna karşın ithalatta düşüş eğilimi görülmektedir. Römorklar ve yarı römorklar alt grubun endeks siralamalarıve 2016 yılı ihracat-ithalat rakamları Tablo 7'de sunulmuştur:

Tablo 7: 786-Römorklar ve Yarı Römorklar

\begin{tabular}{llll}
\hline Ülke adı & İhracat (\$) & İthalat (\$) & Grubel-Lloyd Endeksi \\
\hline Almanya & 92.176 .204 & 103.764 .899 & 0,94 \\
\hline İrlanda & 25.788 & 22.446 & 0,93 \\
\hline Belçika & 4.843 .550 & 5.805 .198 & 0,90 \\
\hline Hong Kong & 39.829 & 49.108 & 0,89 \\
\hline ABD & 1.102 .541 & 1.513 .500 & 0,84 \\
\hline Finlandiya & 303.617 & 203.349 & 0,80 \\
\hline İngiltere & 1.263 .679 & 776.835 & 0,76 \\
\hline İspanya & 2.289 .950 & 4.250 .203 & 0,70 \\
\hline Macaristan & 960.030 & 1.782 .615 & 0,70 \\
\hline İtalya & 11.026 .222 & 3.549 .341 & 0,48 \\
\hline
\end{tabular}

Kaynak: (TÜIK, 2017).

Tablo 7'ye göre Türkiye'nin Almanya, İrlanda ve Belçika ile EİT performansının yüksek olduğu ancak İrlanda ile ticaret hacminin düşük olduğu görülmektedir. Türkiye'de 2016 yılında 66.915 traktör üretilmiş, genel olarak işletmelerin alım gücünün zayıf olması sebebiyle bunların büyük bir bölümü 100 beygir gücüne kadar olan traktörlerden oluşmaktadır. Yerli sanayi tarafından üretimi rasyonel olmayan veya know-how'a dayanan unsurlara sahip olan büyük model tarım makineleri gibi araçlar ise ithalat yoluyla sağlanmaktadır (İleri, 2017). 786 alt grubunda GL endeks değerlerine göre Türkiye ile Almanya ve İrlanda arasında yüksek düzeyde EITT yapısı mevcut olduğu sonucuna varılmıştır. 


\section{SONUÇ}

Otomotiv sektörü Türkiye'de yarattığı katma değer, istihdam ve ilişkili olduğu sanayi dallarıyla birlikte önem derecesi yüksek olan bir sektördür. Sektördeki ticaretin endüstriler aras1 veya endüstri içi yapıya sahip olup olmadığının sorgulanması da önem taşımaktadır. Bu çalışmada 2016 yılı için otomotiv sektörünün 6 alt grubu üzerinden Türkiye ile ihracat ve ithalat yapan ülkelerle Türkiye arasındaki ticaretin yapısı analiz edilmiştir. Tablo 8'de otomotiv sektöründeki tüm alt grupların endeks değerleri toplu halde sunulmuştur:

Tablo 8: Otomotiv Sektörü Alt Grupların Grubel-Lloyd (G-L) Endeks Değerleri

\begin{tabular}{lllllllllllll}
\hline \multicolumn{1}{c}{$\mathbf{7 8 1}$} & \multicolumn{2}{c}{$\mathbf{7 8 2}$} & \multicolumn{2}{c}{$\mathbf{7 8 3}$} & \multicolumn{2}{c}{$\mathbf{7 8 4}$} & \multicolumn{2}{c}{$\mathbf{7 8 5}$} & \multicolumn{3}{c}{$\mathbf{7 8 6}$} \\
\hline Ülke & G-L & Ülke & G-L & Ülke & G-L & Ülke & G-L & Ülke & G- & Ülke & G-L \\
\hline İngiltere & 0,97 & Almanya & 0,99 & Belçika & 0,92 & Fransa & 0,93 & Kanada & 0,85 & Almanya & 0,94 \\
\hline Surbistan & 0,79 & Özbekista & 0,98 & Almany & 0,67 & Romanya & 0,92 & Polonya & 0,80 & İlanda & 0,93 \\
\hline ABD & 0,70 & Polonya & 0,97 & Portekiz & 0,56 & Almanya & 0,84 & Hong Kong & 0,70 & Belçika & 0,90 \\
\hline Polonya & 0,65 & Avusturya & 0,83 & İsveç & 0,52 & İspanya & 0,84 & İspanya & 0,63 & Hong & 0,89 \\
\hline Finlandiya & 0,63 & Hırvatista & 0,80 & İspanya & 0,47 & Vietnam & 0,83 & Almanya & 0,58 & ABD & 0,84 \\
\hline Macaristan & 0,63 & İtalya & 0,53 & Holland & 0,38 & Kanada & 0,79 & Fransa & 0,55 & Finlandiya & 0,80 \\
\hline İspanya & 0,60 & İran & 0,52 & İran & 0,27 & Avusturya & 0,79 & İtalya & 0,49 & İngiltere & 0,76 \\
\hline Fransa & 0,53 & İspanya & 0,51 & Fransa & 0,24 & İngiltere & 0,76 & Avustralya & 0,40 & İspanya & 0,70 \\
\hline Fas & 0,47 & Kirgizista & 0,48 & Polonya & 0,21 & Macaristan & 0,70 & Danimarka & 0,40 & Macaristan & 0,70 \\
\hline
\end{tabular}

Kaynak: (TÜİK, 2017).

784-Motorlu taşıtların aksam ve parçaları ile şase ve karoserleri alt grubunda ve 786Römorklar ve yarı römorklar alt grubundaki ilk 10 ülke ile Türkiye'nin ticaret G-L endeks değeri en düşük 0,70 olduğundan yüksek seviyede EİT gözlemlenmiştir. Diğer alt gruplarda ise ilk sıradaki ülkelerin haricinde tüm ülkelerle Türkiye arasında EAT şeklinde ticaret yapısı mevcuttur. Otomotiv sektörünün alt grupları göz önüne alındığında en çok ihracat yapılan alt grupların 781, 782 ve 784 alt grupları olduğu, en çok ithalat yapılan alt grupların ise 781 ve 784 olduğu görülmektedir. Sektörün büyük bir kısmını temsil eden bu alt gruplar üzerinden inceleme yapıldığında 781 Motorlu yolcu taşıtları (binek otomobilleri vb.) alt grubunda ve 782 Eşya taşımaya mahsus motorlu taşıtlar alt grubunda Türkiye'nin 8 ülke ile EITT'ye sahip olduğu, 784 Motorlu taşıtların aksam ve parçaları ile şase ve karoserleri alt grubunda ise 19 ülke ile EİT'ye sahip olduğu görülmektedir.Türkiye'nin 2016 yılında 781 ve 784 alt grubunda ihracat ve ithalat değerleri birbirine yakın, 782 alt grubunda net ihracatçı konumunda bulunmaktadır. Türkiye genel olarak 78 kodlu otomotiv sektöründe 2016 yılında 19.274.169.262 dolar ihracat, 17.389.922.127 dolar ithalat gerçekleştirmiştir.

Türkiye'nin ekonomik büyümesine paralel olarak sektörün de kararlı biçimde büyümesi için doğrudan yabancı yatırımların artması, teknoloji yoğunluklu üretimin ve yatırımın artırılması, üretim ve istihdam artışı sağlayacak büyük ve köklü firmaların Türkiye'de üretim yapmalarına olanak verecek yasal çerçevenin ve teşviklerin yapılması gerekmektedir. Bununla birlikte ithalata bağımlılığın azaltılarak hammadde, ara mallar ve ileri teknoloji ürünlerin üretimi ve ihracatının artırılması teşvik edilmesi gerekmektedir. 


\section{KAYNAKÇA}

Abd-El Rahman, K.S. (1991). Firms competitive and national comparative advantages as joint determinant of trade composition. WeltwirtschaftlichesArchiv, 127 (1), 83-97.

Akal, M. (2008). Ortadoğu sınır ülkeleriyle dış ticaret yoğunlaşması ve yapısal değişim. Gaziantep Üniversitesi Sosyal Bilimler Dergisi, 7(2), 271-296.

Altay, H., Özcan, S. E., ve Çınar, İ. T. (2015). Türkiye'nin Avrupa Birliği (15) pazarında endüstriler-arası ve endüstriiçi ticaret açısından avantajlı olduğu ürün gruplarının belirlenmesi: 1995-2007. Dumlupınar Üniversitesi Sosyal Bilimler Dergisi, 23(23).

Altay, H. ve Șen, A. (2009). Türkiye'nin Avrupa Birliği (15) pazarındaki endüstri-içi ticaret performansının rakip ülke performanslarıyla karşılaştırmalı analizi: 1995-2007. Dumlupınar Üniversitesi Sosyal Bilimler Dergisi, 25, 127-140.

Ando, M. (2006), Fragmentation and vertical Intra-industry trade in East Asia. North American Journal of Economics and Finance, 17, 257-280

Aturupane, C., Djankov, S. \& Hoekman, B. (1997). Determinants of intra-industry trade between East and West Europa, 1850. World Bank Working Papers.

Aydın, A. (2008). Türkiye ekonomisinde endüstri içi ticaretin yapısı. Yönetim ve Ekonomi Araştırmaları Dergisi, 6(9), 73-96.

Aydın, A. (2010). Türkiye'nin ticari hizmetler endüstri içi ticareti. Ekonomi Bilimleri Dergisi, 2(2), 1-10.

Balassa, B. (1966). Tarif reductions and trade in manufacturers among the industrial countries. The American Economic Review, 56(3),471.

Balassa, B. \& Bauwens, L. (1987). Intra-industry specialization in a multicountry and multi-industry framework. The Economic Journal, 97, 388, 923-939.

Balassa, B., (1986). The determinants of intra-industry specialization in the United States trade. Oxford Economic Papers, 38, 220-233.

Baleix J. M. \& Egido, A.I. (2005). Trade types with developed and developing countries what can we learn from Spanish data?. Working Papers DEFI 05-06.

Başkol, M. O. (2009). Türkiye'nin endüstri-içi ticaretinin analizi. Uludă̆ Üniversitesi İktisadi ve İdari Bilimler Fakültesi, XXVII, 2, 1-24.

Başkol, M. O. (2010). Türkiye ile Orta Asya Türk Cumhuriyetleri arasındaki endüstri-içi ticaretin analizi. International Conference on Eurasian Economies, 386-391.

Bergstrand, J. H., (1990). The Heckscher-Ohlin-Samuelson model, the Linder hypothesis, and the determinants of bilateral intra-industry trade. Economic Journal, 100(403), 1216-1229.

Blanes, J.V. \& Martin, C. (2000). The nature and causes of intra-industry trade: back to the comparative advantage explanation? The case of Spain. Weltwirtschaftliches Archiv/Review of World Economics, 136(3), 600-613.

Byun, J. J. \& Lee, S. H. (2005). Horizontal and vertical intra-industry trade: new evidence from Korea, 1991-1999. Global Economy Journal, 5(1), 1-29.

Caetano J. \& Galego A. (2007). In search for determinants of intra-industry trade within an enlarged Europe. SouthEastern Europe Journal of Economics, 5(2), 163.

Clark, D. P. (1993). Recent evidence on determinants of intra-industry trade. Weltwirtschaftliches Archiv, 129, 332344. 
Clark, D. P. \& Stanley, D. L. (1999), Determinants of intra-industry trade between developing countries and the United States. Journal of Economic Development, 24(2), 79-92.

Caves, R. E. (1981). Intra-industry trade and market structure in the industrial countries. Oxford Economic Papers, 33, 203-223.

Çalışkan, Ö. (2010). Türkiye-AB ticaretinde endüstri-içi ticaret olgusu, 1990-2007. Hacettepe Üniversitesi İIBF Dergisi, 28(2), 1-45.

Deviren, N. V. (2004). Türkiye ile Avrupa Birliği ülkeleri arasındaki sınai ürünleri endüstri içi ticareti. Iktisat Isletme ve Finans, 19(222), 107-127.

Ekanayake, E. M. (2001), Determinants of intra-industry trade: thecase of Mexico. The International Trade Journal, 15(1), 89-112.

Emirhan, P. N. (2014). Uluslararasi emek göçü ve diş ticaret arasındaki iliski: Türkiye için bir uygulama. Ege Akademik Bakis, 14(4), 611.

Erlat, G. ve Erlat, H. (2012). Türkiye'nin Orta Doğu ülkeleri ile olan ticareti, 1990-2002 (No.2012/26). Discussion Paper, Turkish Economic Association.

Erün, G. (2010). Türkiye ile AB, gıda ve canlı hayvan sektörü dış ticaretinde endüstri içi ticaret analizi, Ekonomi Bilimleri Dergisi, 2(1), 71-78.

Eşiyok, B. A.(2014). Türkiye-AB arasında dış ticaretin teknolojik yapısı, rekabet gücü ve endüstri-içi ticaret: ampirik bir değerlendirme. Ankara Avrupa Çalışmaları Dergisi, 13(1), 91-124.

Falvey, R. (1981). Commercial policy and intra-industry trade. Journal of International Economics, 11, 495-511.

Fontagne, L. \& Freudenberg, M. (2002), Long-term trends in intra-industry trade, Chapter 8, Frontiers of research on intra industry trade içinde, H. Grubeland H.-H. Lee (ed.), Palgrave, London.

Fontagne L., M., Freudenberg \& Gaulier, G. (2006). A systematic decomposition of world trade in to horizontal and vertical IIT, Review of World Economics. Weltwirtschaftliches Archiv, 142(3), 459-475.

Fukao, K., H. Ishido, \& Ito, K. (2003). Vertical intra-industry trade and foreign direct investment in East Asia. Journal of the Japanese and International Economies, Issue 4, December 2003, 17, 468-506.

Greenaway, D., R., Hine, \& Milner, C. (1994). Country-specific factors and pattern or horizontal and vertical intraindustry trade in the UK. Weltwirtschaftliches Archiv, 130(1), 77-100.

Greenaway, D., R., Hine \& Milner, C. (1995). Vertical and horizontal intra-industry trade: a cross industry analysis for the United Kingdom. Economic Journal, 105, 1505-1519.

Gullstrand, J., (2002). Does the measurement of intra-industry trade matter?. Weltwirtschaftliches Archiv, 138(2), 317 339.

Grubel H. G. \& Lloyd, P. J. (1971). The empirical measurement of intra industry trade. Economic Record, 47(4), 494517.

Grubel, H. G. \& Lloyd, P. J. (1975). Intra-industry trade: The theory and measurement of international trade in differentiated products, Macmillan, London.

Havas, A. (1997). Foreign direct investment and intra-industry trade: the case of the automotive industry in central Europe, in D. Dyker (ed.) The technology of transition: Science and technology policies for transition countries, Budapest, Central European University Press, 211-240.

Hellvin, L. (1996). Vertical intra-industry trade between China and OECD countries. OECD Development Technical Papers, No. 114: 1-37. 
Hu, X. \& MA, Y. (1999). International intra-industry trade of China. Weltwirtschaftliches Archiv/Review of World Economics, 135, 82-101.

Hughes, K. (1993). Intra-industry trade in the 1980s: a panel study. Welwirtschaftliches Archiv, 129, 560-572.

Hummels, D. \& Levinsohn, J. (1995). Monopolistic competition and international trade: reconsidering the evidence. Quarterly Journal of Economics, 110, 799-836.

İleri, M.S. (2017). Türkiye tarım makinaları sektör raporu, Tarmakbir, Türk Tarım Alet ve Makineleri İmalatçılar Birliği, Ankara.

İyibozkurt, E. ve Başkol, M. O. (2005). Sanayi-içi ticaret (endüstri-içi ticaret) ve otomotiv sektörü, TMMOB Makine Mühendisleri Odası, Otomotiv Sanayi Sempozyumu, Bursa.

Konyalı, G. ve Emirhan, P. N. (2004). Türk cam sanayii ve seramik sanayiinin Avrupa Birliği piyasasındaki ticaret yap1s1 ve ihracat performans1, Anadolu Üniversitesi Sosyal Bilimler Enstitüsü Dergisi, 4(2), 27-40.

Kutlu, E. ve Yenilmez, F. (2005). Türkiye ile Avrupa Birliği ülkeleri arasındaki endüstri içi ticaretin önemi. Iktisat Isletme ve Finans, 20(229), 45-64.

Küçükahmetoğlu, O. (2001). Endüstri içi ticaret ve Türkiye, Avrupa Araştırmaları Dergisi, 9(2), 129-153.

Küçüksakarya, S. (2016). Türkiye'nin serbest ticaret anlaşmaları kapsamında endüstri-içi ticareti üzerine bir inceleme, Aksaray Üniversitesi İktisadi ve İdari Bilimler Fakültesi Dergisi, 8(2), 27-41.

Lee, Y. S. (1989). A study of the determinants of intra-industry trade among the Pacific basin countries. Review of World Economics/ Weltwirtschaftliches Archiv, 125(2), 346-358

Leitao, N.C., H.C., Faustino \& Yoshida, Y. (2009). Intra-industrytrade in the automobile components industry: An empirical analysis. Journal of Global Business and Technology, 5(1), 31-41.

Lettice, F., Wyatt, C., \& Evans, S. (2010). Buyer-supplier partnerships during product design and development in the global automotive sector: Who invests, in what and when?. International Journal of Production Economics, 127(2), 309-319.

Loertscher, R., \& Wolter, F. (1980), Determinants of intra-industry trade among countries and across industries. Review of World Economics, 116(2), 280-293.

Londra Ticaret Müşavirliği (2007), İngiltere otomotiv sektörü, [Çevrim-içi: http://www.ekonomi.gov.tr/portal/faces/], Erişim Tarihi: 15.05.2017.

Özkaya, M. H. (2010). Tekstil sektöründe endüstri-içi ticareti etkileyen faktörler üzerine ampirik çalışma. Uşak Üniversitesi Sosyal Bilimler Dergisi, 3(2), 136-157.

Özpeynirci, E. (2016, 4 Temmuz). Ford Otosan ve Tofaş'tan sonra Toyota'da ABD’ye Türkiye'den araç ihraç edecek. Hürriyet.

Pişkin, S. (2017). Otomotiv sektör raporu: Türkiye otomotiv sanayii rekabet gücü ve talep dinamikleri perspektifinde 2020 iç pazar beklentileri. TSKB Ekonomik Araştırmalar, İstanbul.

Pittiglio, R., \& Reganati, F. (2012). Vertical intra-industry trade in higher and lower quality: a new approach of measuring country specific determinants. International Journal of Economics and Business Research, 4, Nos. 1/2.

Şahin, D. (2015). Türk tekstil ve hazır giyim sektörünün endüstri-içi ticaretinin statik analizi: AB-15 ülkeleri ile karşılaştırma. Uşak Üniversitesi Sosyal Bilimler Dergisi, 22.

Şahin, D. (2016a). Yaş meyve ve sebze sektörünün dış ticaret yapısının analizi: Türkiye ve BRIC ülkeleri örneği. Adnan Menderes Üniversitesi Sosyal Bilimler Enstitüsü Dergisi, 3(2). 
Şahin, D. (2016b). Türkiye'de ormana dayalı sektörlerin dış ticaret yapısının analizi. Bitlis Eren Üniversitesi Sosyal Bilimler Enstitüsü Dergisi, 5(ek), 181-196.

Sağbaş, İ. (2004). Kamu harcamaları nüfus ölçek ekonomileri ilişkisi: Türkiye üzerine ampirik bir çalışma. Kentsel Ekonomik Araştırmalar Sempozyumu, Cilt: 2, 166-184,

Şentürk, C. (2014). Türkiye'nin seçilmiş ülkeler ile endüstri içi ticaretinin endeks yöntemine dayalı analizi. Süleyman Demirel Üniversitesi Sosyal Bilimler Enstitüsü Dergisi, 2014/2(20), 207-230.

Şentürk, C. (2016). Endüstri içi ticaretin belirleyicileri üzerine bir literatür incelemesi. Süleyman Demirel Üniversitesi Sosyal Bilimler Enstitüsü Dergisi, 2016 (CIEP özel sayısı), 859-890.

Şentürk, C., ve Kösekahyaoğlu, L. (2014). Türkiye'nin endüstri içi ticaretinin ülke ve politika temelli belirleyicilerine yönelik bir uygulama. İktisadi ve İdari Bilimler Dergisi, 36(2), 299-325.

Şentürk, C., ve Kösekahyaoğlu, L. (2015). Türkiye'nin 1990-2013 dönemi için endüstri içi ticaretinin endeks yöntemine dayalı analizi. Süleyman Demirel Üniversitesi İktisadi ve İdari Bilimler Fakültesi Dergisi, 20(1), 169-197.

Sharma, K., (2002). How important is processed food in intra-industry trade? The Australian experience. Journal of Economic Studies, 29, 121- 130.

Sharma K., (2004). Horizontal and vertical intra-industrytrade in Australian manufacturing: Does trade liberalization have an impact?. Applied Economics, 36, 1723-1730.

Şimşek, N. (2005). Türkiye'nin yatay ve dikey endüstri-içi dış ticareti. D.E.Ü.İ.̇.B.F. Dergisi, 20(1), 43-62.

Stone, J. A. \& Lee, H. H. (1995). Determinants of intra-industry trade: a longitudinal, cross-country analysis. Weltwirtschaftliches Archiv/Review of World Economics, 131, 67-85.

T.C. Gümrük ve Ticaret Bakanlığı, (2016). Otomotiv Sektörü, Risk Yönetimi ve Kontrol Genel Müdürlüğü Ekonomik Analiz ve Değerlendirme Dairesi, 10.06.2016, Ankara.

Tharakan, P. K. \& Kerstens, B. (1995). Does north-south horizontal intra industry trade really exist? An analysis of the toy industry. Weltwirtschaftliches Archiv, 131, 86-105.

Toh K. (1982). A cross-section analysis of intra-industry trade in U.S. manufacturing industries. Weltwirtschaftliches Archiv, 118(2), 282-301.

TÜIK, (2017). Dış Ticaret İstatistikleri Veritabanı, Türkiye İstatistik Kurumu (TÜIK), [Çevrim-içi: http://www.tuik.gov.tr], Erişim Tarihi:15.05.2017.

Türkiye İhracatçılar Meclisi (2016), [Çevrim-içi: http://www.tim.org.tr/tr/ihracat-arastirma-raporlari-ilk-1000ihracatci-arastirmasi.html], Erişim Tarihi: 12.05.2017.

UNSD (2017). The United Nations Statistics Division, [Çevrim-içi:https://unstats.un.org], Erişim Tarihi: 15.05.2017.

Utkulu, U. (2005), Türkiye'nin dış ticareti ve değişen mukayeseli üstünlükler. Dokuz Eylül Üniversitesi Yayınları, İzmir.

Yenigün, H. (2016, 26 Haziran). Türk otomotiv sanayinin en büyük müşterisi İngiltere. Hürriyet.

Yenilmez, F. (2004). Türkiye'nin Avrupa Birliği ile dış ticaretinde endüstri içi ticaret (Türkiye-Almanya Örneği). $T O B B$, Ankara. 